This is the author's Post-print version (final draft post-refereeing as accepted for publication by the journal). The definitive, peer-reviewed and edited version of this article is published as: Tammaru T., van Ham M., Leetmaa K. \& Kährik A. (2013) Ethnic dimensions of suburbanisation in Estonia. Journal of Ethnic and Migration Studies 39(5), 845-862. http://dx.doi.org/10.1080/1369183X.2013.756697

\title{
The Ethnic Dimensions of Suburbanisation in Estonia
}

Tiit Tammaru, Maarten van Ham, Kadri Leetmaa, Anneli Kährik and Kristiina Kamenik

Large-scale suburbanisation is a relatively recent phenomenon in East Central Europe and is responsible for major socio-spatial changes in metropolitan areas. Little is known about the ethnic dimensions of suburbanisation, despite the existence of often sizeable Russian minority populations in some member-states of the former Soviet Union. We use individual-level Estonian census data from the year 2000 in order to investigate the ethnic dimensions of suburbanisation. The results show that ethnic minorities have a considerably lower probability of suburbanising compared to the majority population, and minorities are less likely to move to rural municipalities - the main sites of suburban change-in the suburban ring of cities.

Keywords: Suburbanisation; Ethnicity; Census Data; East Central Europe; Estonia

\section{Introduction}

In many formerly centrally planned countries in Eastern Europe, the land use of places within commuting distance from larger cities has changed dramatically since the beginning of the 1990s. Many of these places have lost their formerly agricultural and industrial character and have been transformed into suburban residential and service areas (Borén and Gentile 2007; Hirt 2006; Krišjāne and Bērziņš 2011; Leetmaa et al. 2009; Marcińczak and Sagan 2011; Ouředníček 2007; Timár and Váradi 2001). The new inhabitants of these suburban areas are mostly affluent households who have left cities in search of better-quality housing and living environments reflecting their (new) socio-economic status (Golubchikov and Phelps 2011; Kährik and Tammaru 2008; Ouředníček 2007). Less is known about the ethnic dimensions of suburbanisation, despite the existence of often-sizeable Russian minority populations in some member-states of the former Soviet Union.

Studies in Western European countries and the US have shown clear ethnic dimensions to suburbanisation (Bolt et al. 2008; Clark 2006; Goodwin-White 2007; Li 2009; Lichter et al. 2010; Massey and Denton 1988; Stillwell and Hussain 2010; Teixeira 2007). In these countries, ethnic minorities are often less likely to move to more affluent middle-class suburbs and tend to concentrate within a limited number of neighbourhoods in urban areas. Such residential careers are partly due to socio-economic differences between ethnic minority

\footnotetext{
Tiit Tammaru is in the Centre for Migration and Diaspora Studies at the University of Tartu, Estonia. Correspondence to: Dr T. Tammaru, Centre for Migration and Diaspora Studies, Dept of Geography, University of Tartu, Vanemuise 46, Tartu 51014, Estonia. E-mail: tiit.tammaru@ut.ee. Maarten van Ham is Professor of Urban Renewal at the OTB Research Institute for the Built Environment at Delft University of Technology, the Netherlands \& University of St Andrews, UK. Kadri Leetmaa, Anneli Kährik and Kristiina Kamenik are in the Centre for Migration and Diaspora Studies at the University of Tartu, Estonia.
} 
and majority groups. Other explanations given are ethnic differences in knowledge about regional housing markets, differences in search behaviour, discrimination and the limited language skills of ethnic minorities. Although there are large differences in both the ethnic composition of populations and the history and spatial patterns of urban development between Western Europe and the US, and Eastern European countries, it can be expected that, in the formerly centrally planned Eastern European countries, too, there is an ethnic dimension to suburbanisation.

This study will investigate the ethnic dimensions of suburbanisation in Estonia. Estonia was part of the Soviet Union between 1944 and 1991, and experienced large-scale immigration, mainly from Russia, during this period. Ethnic minorities form about a third of the Estonian population. The country underwent significant transformation since the disintegration of the Soviet Union in 1991 that either directly or indirectly impacted on ethnic relations as well. For example, post-World War II immigrants were not automatically granted Estonian citizenship (Rannut 2008) which limited their access to some jobs in the public sector. Estonians benefitted from the restitution of residential property and land to the pre-World War II owners, but minorities gained from the housing privatisation that transformed tenants living in the post-World War II apartment houses into home-owners.

Using individual-level census data for Estonia from 2000, we investigate the individuallevel characteristics of those members of the ethnic minority population who moved from cities to suburbs and those who stayed, and the destination choice of minority suburbanisers. We are specifically interested in clarifying the role of socio-economic status (measured by education and occupation) and ties with the majority population and host society (measured by country of birth, partner ethnicity and majority-language proficiency) on the probability of suburbanisation, and on the probability of settlement in rural areas in the suburban ring for ethnic minorities. The latter areas are the main sites of ongoing suburban transformation in many formerly centrally planned countries in Europe, including Estonia, since they provide land for the construction of new residential areas which was previously used for agricultural purposes. In Estonia only a few members of the ethnic minority population lived in rural municipalities in the suburban ring by the end of the Soviet period.

\section{Literature Review of Ethnic Minority Suburbanisation}

Most of the previous research on ethnic minority suburbanisation has been in North American and West European contexts. These studies reveal that ethnic minorities are still more likely to live in core cities than those belonging to majority populations, but there is also an increasing trend towards ethnic minority suburbanisation and dispersal away from their initial concentration areas (Bonvalet et al. 1995; Finney and Simpson 2008, 2009; Stillwell 2010; Stillwell and Hussain 2010; Wen et al. 2009). In this section we review the literature on ethnic differences in suburbanisation rates, and on the destinations and characteristics of minority suburbanisers.

Many studies show that ethnic minorities are not always willing or able to suburbanise at a similar rate to the majority population (Hou 2006; Logan et al. 1996). For example, discriminatory practices towards minorities in the housing and labour markets, or the preference to live together with co-ethnics, could decrease the likelihood that ethnic minorities will leave cities. The literature on 'white flight' suggests that high concentrations of ethnic minorities in cities could lead to higher out-migration rates for the majority population (Bolt et al. 2008; Crowder et al. 2011; Frey and Liaw 1998; van Ham and Clark 2009; van Ham and Feijten 2008). For example, in the UK it has been found that members of both the minority and the majority populations leave ethnic areas, but minorities do it at a somewhat lower rate (Simpson and Finney 2009). Such differences in out-migration rates 
imply that ethnic minority concentration could increase in the cities even when some of the minority do suburbanise and leave their initial concentration areas.

Most of the research on minority suburbanisation focuses on the destinations of minority suburbanisers and the effects of minority suburbanisation on residential segregation or integration with the majority population. Several studies find evidence that suburbanisation increases ethnic co-residence (Clark 2006; Kraus and Koresh 1992; Logan et al. 1996). This is partly explained by the similarity of the causes that shape residential choices of both minority and majority populations (Finney and Simpson 2008, 2009; Newbold 1996). Moves to suburban areas are strongly related to life-course events, housing needs and increased personal wealth. Minority ties with the host country (for example, the immigrant generation) have also been found to increase suburban ethnic co-residence (Alba et al. 1999; Brubaker 2001; Painter and Zhou 2008). In short, when the socio-economic status of ethnic minorities improves, and when they develop stronger ties with their host society, they are more likely to move to suburban locations with relatively high percentages of the majority population (Bolt and van Kempen 2010; Massey and Denton 1988).

Other studies do not find evidence of increased ethnic co-residence as a result of minority suburbanisation. Clark (1991) introduced the term 'neutral ethnocentrism' in order to characterise the phenomenon that people tend to prefer to live together with other people of 'their own kind'. According to the group affinity hypothesis, social networks and institutional resources are more likely to flourish in large, viable ethnic communities (Hou 2006). The establishment of an ethnic infrastructure (churches, workplaces, schools, shops, restaurants and other leisure-time meeting places) in certain suburban locations starts the processes of circular and cumulative causation that lead to the formation of suburban ethnic clusters, socalled 'ethnoburbs' (Barrett and McEvoy 2006; Li 2009; Lichter et al. 2010; Muñoz 2011). But ethnic concentrations in the suburbs are not necessarily the result of choice. The structure of the housing market (e.g. the provision of public housing) or the perceived threat of discrimination in non-ethnic areas (Bobo and Zubrinsky 1996; Bonvalet et al. 1995; Krysan and Farley 2002; Pamuk 2004; Randolph and Holloway 2005) could contribute to ethnic separation in the suburbs.

\section{[FIGURE 1 ABOUT HERE]}

We have summarised the above literature review into three theoretical models of minority and majority suburbanisation and how these can change the ethnic landscape in metropolitan areas (Figure 1). Model 1 is characterised by a low suburbanisation rate of ethnic minorities and a high suburbanisation rate of the majority population. The result is an increasing concentration of ethnic minorities in the city. Model 2 is characterised by the suburbanisation of all ethnic groups, which leads to increasing minority-majority co-residence in metropolitan space. Model 3 is characterised by minority suburbanisation to specific locations in the suburban ring, leading to suburban ethnic clusters.

\section{Urban Change in Formerly Centrally Planned Countries in Europe}

The evolution of metropolitan areas in the Soviet Union and East Central Europe had some specific features. The drive towards industrialisation and constant housing shortages led to the construction of large standardised high-rise housing estates in larger cities in the 1960s, 1970s and 1980s (Kährik and Tammaru 2010; Smith 1996; Temelová et al. 2011). Such housing spread into the suburban ring in the 1970s, mainly as a result of the policies to develop industrial satellite towns to curb the growth of larger cities (Lappo 1992). Detached housing remained the dominant type in rural areas in the suburban ring, although some prefabricated 
apartment blocks were built in those rural settlements that became the centres of agricultural production. Detached houses were almost exclusively built by home-owners themselves and the construction often took several years of hard work (Konrád and Szelényi 1974; Smith 1996).

The high attraction of subsidised urban apartments on the one hand, and self-construction as an important means of access to suburban detached housing on the other, caused socio-spatial differentiation of the population (Konrád and Szelényi 1974; Smith 1996). People with a higher social status were over-represented in cities and in urban apartments, while those with a lower social status were over-represented in suburban areas and in detached houses (Kulu 2003; Tammaru and Leetmaa 2007). In other words, a reverse pattern of socio-spatial differentiation emerged compared to many metropolitan areas in Western Europe and North America (Sýkora 2009).

In the former Soviet Union, ethnicity was an additional element of metropolitan-level sociospatial differentiation. The related processes of immigration and industrialisation, and the central allocation of housing, led to high levels of ethnic residential segregation (Gentile and Sjöberg 2010; Gentile and Tammaru 2006; Kulu 2003). New housing with modern facilities in core cities and satellite towns was preferentially allocated to Russian and other Slavic immigrants (Kulu 2003; Smith 1996), whereas the native population remained overrepresented in the prewar housing stock and rural areas within the suburban ring (Tammaru 2001). The dissimilarity index for ethnic minorities is 41 in the capital city, Tallinn (cf. Peach 2010: 1390 for the UK and Crowder et al. 2009: 222 for US cities).

To conclude, by the end of the Soviet period, two distinct areas had emerged in the suburban ring around larger cities; industrial satellite towns with mainly urban apartments and high concentrations of (Russian and other) immigrant populations, and rural areas dominated by agricultural activities, with mainly detached housing and a low presence of immigrant populations. After the fall of the Soviet Union, agricultural production collapsed in many rural areas in the suburban rings, which meant that this land became available for new residential suburban developments (Leetmaa et al. 2009).

\section{Ethnic Minorites in Estonia}

Immigration played a decisive role in forming the Estonian population as we know it today. After Estonia lost its independence and became part of the Soviet Union in 1944, immigration from Russia was stimulated by political and ideological motives which brought not only members of the communist party and Soviet military personnel to Estonia, but also large numbers of workers for the manufacturing and construction industries (Katus and Sakkeus 1993). Immigrants were especially needed in these two expanding sectors since Estonia had a strategic role to supply food for areas of the Soviet Union, keeping a significant part of ethnic Estonians engaged in agriculture and living in rural areas through the end of the Soviet period (Tammaru 2001).

Today, Russians form 26 per cent of the total population (1.37 million) and 80 per cent of the minority population ( 0.44 million). Other large ethnic groups are Ukrainians (7 per cent of minorities), Byelorussians (4 per cent) and Finns ( 3 per cent). Note that, as a result of the Soviet legacy, most of the Ukrainians and Byelorussians also use Russian as their mother tongue and therefore they are often labelled together with Russians as a 'Russian-speaking' minority population in Estonia (Vihalemm 1999). Immigrants became strongly overrepresented in large cities, where they were allocated dwellings in new standardised high-rise housing estates (Kährik and Tammaru 2008). They were provided with an ethnic infrastructure - such as Russian-speaking kindergartens and schools. All this implied that inter-ethnic contacts remained modest both at places of residence and at work and, as a result, 
the Estonian language proficiency of immigrants remained poor (Vihalemm 1999) and the rate of intermarriage with the native population remained modest (van Ham and Tammaru 2011). The break-up of the Soviet Union had important ethnic implications.

First, in the process of nation-building, the position of Russians changed dramaticallyfrom being the largest and most powerful ethnic group in the former Soviet Union, they now suddenly became a minority group in the independent states (Laitin 1998). In Estonia, the two most important elements of this nation-building process were related to language and citizenship policies (Rannut 2008). Estonian language replaced Russian as the official language of the country. The decisive precondition for getting Estonian citizenship was proficiency in the Estonian language (Lindemann 2009). The language requirement was farreaching, as many Russian immigrants who had lived in Estonia for a long time, or who were even born in Estonia, did not qualify for Estonian citizenship because of a lack of language skills. According to the 2000 census, around 40 per cent of the ethnic minorities in Estonia had Estonian citizenship, 19 per cent were Russian citizens, and as many as 38 per cent had no citizenship at all (Tammaru and Kontuly 2010).

Second, ethnic minorities in Estonia suffered more than the native population from the shift from a Soviet-period industry-based economy to a service-based economy (Toomet 2011). Ethnic minorities were over-represented in declining economic sectors, and faced larger obstacles when searching for new jobs in services and the public sector, partly because of their low Estonian language proficiency and their lack of Estonian citizenship (Lindemann 2009). This is reflected in changes in occupational structure - for example, we can observe a large decrease in minority employment in public administration (Tammaru and Kulu 2003). Such a decreased share occurred in most of the former satellite states of the Soviet Union in the beginning of the 1990s (Kaiser 1995) and is partly related to the nation-building processes that took place at that time.

\section{Hypotheses}

Our literature review on patterns and processes of ethnic minority suburbanisation, the features of the ongoing (sub)urban change in the formerly centrally planned countries in Europe, and the changes in the relative position of ethnic minorities in Estonia since the demise of the Soviet Union lead us to two hypotheses on ethnic differences in suburbanisation in Estonia.

Hypothesis 1: Ethnic minorities are less likely to move from cities to the suburban ring.

There are several reasons to expect ethnic minorities to be less likely to move to the suburbs than the majority population in Estonia. First, the ethnic infrastructure, including Russianlanguage schools, is the most dense in the cities. Second, Estonians have more economic resources with which to improve their housing conditions and residential location within the metropolitan space than ethnic minorities. Third, the housing conditions of many Estonian households living in cities were worse than those of ethnic minorities at the end of the Soviet period (Kulu 2003). All these factors lead us to expect a higher suburbanisation rate among ethnic Estonians than among ethnic minorities. If this hypothesis is correct, this will lead to an increasing concentration of ethnic minorities in cities (see Figure 1, Model 1).We expect that the probability of moving to rural municipalities in the suburban ring is especially low among the members of the ethnic minority population since this implies moving away from the established minority settlement areas. 
Hypothesis 2: Higher socio-economic status and stronger ties with the majority population increase the probability that members of the ethnic minority population move to rural destinations in the suburban ring.

Studies in other immigrant countries do not provide conclusive evidence of those minority characteristics that lead to an increase of minority-majority co-residence in suburban areas. For example, it has been found that minorities with a higher socio-economic status move to both majority-dominated (Clark 2006; Logan et al.1996) and minority-dense (Li 2009; Wen et al. 2009) suburban destinations. The context of suburban change in Estonia leads us to expect that minorities with a higher socio-economic status would be more likely to settle in rural destinations in the suburban ring (Figure 1, Model 2). Rural areas around cities are the main sites of contemporary suburban transformation, offering better opportunities for the improvement of housing conditions (Kährik and Tammaru 2008). Following previous studies, we also expect that stronger ties with the majority population and the host society would increase the probability that ethnic minorities move to non-ethnic destinations-rural areas within the suburban ring (Figure 1, Model 2). Weak ties with the majority population and the host society would increase the probability of moves to secondary ethnic clusters - satellite towns within the suburban ring (Figure 1, Model 3).

\section{Data and Methods}

This study uses anonymous individual-level data from the 2000 Estonian census. The data include the entire population living in the 15 urban regions of Estonia (Figure 2). A 'core city' or city is defined as a continuous built-up area, which includes both the inner-city area, Soviet-era high-rise housing estates and some older areas with detached housing from the interwar and Soviet periods. All municipalities from where at least 30 per cent of the workers commute to the core city are part of the 'suburban ring'. We define suburbanisation as a process of intra-metropolitan population dispersal-moves from core cities to the suburban rings. There are 660,495 'stayers' who lived in core cities in both 1989 and 2000, and 36,626 suburbanisers who lived in core cities in 1989, but in suburban rings in 2000.

\section{[FIGURE 2 ABOUT HERE]}

We distinguish three types of urban region: the capital city, regional town, and county-seat urban areas. We further distinguish two residential contexts within the suburban rings of those urban regions. Rural municipalities represent areas with a low population density, a high share of detached houses and a low share of minority population (on average 10 per cent). Urban municipalities in the suburban ring (Soviet-era satellite towns) represent a quite different suburban residential context, with a high share of apartments and ethnic minorities (43 per cent). Moves of ethnic minorities from core cities to rural municipalities in the suburbs could be seen as moves away from ethnic concentration areas increasing ethnic co-residence (spatial assimilation), since only a few members of the minority population lived in these areas during the Soviet period. Moves of ethnic minorities to urban municipalities in the suburbs could be seen as moves to secondary ethnic clusters, since these areas already had a sizeable minority presence during the Soviet period.

\section{[TABLE 1 ABOUT HERE]}

There are some important compositional differences between members of the minority and the majority populations in Estonia (Table 1). First, as one would expect, the migration 
background is different because only 2 per cent of Estonians (but 52 per cent of ethnic minorities) are foreign-born. Estonia already has a large second-generation immigrant population, and a third generation of immigrants is emerging as well. This provides researchers with an excellent opportunity to also study differences in spatial redistribution by immigrant generation. Most of the ethnic minorities live in urban areas and multi-family houses.

To investigate ethnic differences in moves from core cities to the suburban ring, we have fitted multinomial logistic regression models (dependent categories are: stay in core city; move to rural municipality in suburban ring; move to urban municipality in suburban ring). The models can be written as follows:

$\log \frac{p\left(Y_{i}=j\right)_{\mathrm{\kappa}}}{p\left(Y_{i}=J\right)_{\mathrm{k}=1}}=\alpha+\sum \beta_{j k} X_{i k}$

where $p\left(Y_{i}=j\right)$ is an individual's $i=1, \ldots I$ probability of being a suburbaniser to a rural $(j=1)$ or an urban $(j=2)$ municipality, and $p\left(Y_{i}=J\right)$ is the probability of being a stayer in a core city $(J=3) . \alpha$ is the constant and $X_{i k}$ is an individual-level variable; $\beta_{j k}$ is the parameter for this individual-level variable, with $K$ variables. We first estimate a model for the whole population to investigate ethnic differences in suburbanisation and to test Hypothesis 1. The ethnic groups in the model are as follows: Estonian, Russian, Byelorussian, Ukrainian, other ethnicity. The models also include a set of standard control variables. Level of education and occupation both control for the social stratification order since information on income is not available in Estonian census data. Next we estimate a model only including ethnic minorities to test Hypothesis 2. Our main variables of interest characterise different dimensions of ethnicity: self-defined ethnicity (Russian, Byelorussian, Ukrainian, other ethnicity), partner ethnicity (Estonian, other), immigrant generation (first, second, third+), Estonian-language proficiency (speaks Estonian, does not speak Estonian) and citizenship (Estonia, Russian, other country, has not chosen a citizenship).

\section{Results}

There are large ethnic differences in suburbanisation in Estonia.The majority population is over-represented among movers from core cities to the suburban ring: 80 per cent of the suburbanisers are Estonians, who only make up 54 per cent of the population living in core cities. Subsequently ethnic minorities, who make up 46 per cent of the population residing in the core cities, account for only 20 per cent of moves from core cities to the suburban ring. There are also important differences by ethnicity in destinations within the suburban ring. Of those who suburbanise, 86 per cent of Estonians settle in rural municipalities in the suburban ring, compared to only 50 per cent of ethnic minorities. The other half moves to urban satellite towns in the suburban ring.

The choice of destination differs by type of urban region - 37 per cent of ethnic minorities suburbanising from the capital city, Tallinn, have moved to rural municipalities, compared to just over 73 per cent of those who have moved from regional centres and 95 per cent of those who have moved from county-seat cities to rural areas. These differences clearly reflect regional differences in the structure of the housing market, as it is mainly the biggest cities which have urban satellite towns in their suburban rings. A similar relationship between the type of urban region and the destination choice can be found for ethnic Estonians, but the differences are much smaller. 
Table 2 presents multinomial logistic regression models of residential mobility destinations during the 1989-2000 period. The reference category consists of those who are still in the core cities in 2000 . We modelled the probability that people moved to either urban or rural destinations in the suburban ring. The modelling results for the entire population confirm our earlier descriptive findings that Estonians are more likely to suburbanise than ethnic minorities. There are important differences between the two suburban destinations. The ethnic differences in the probability of moving to urban municipalities in the suburban ring are much smaller than those in the probability of moving to rural destinations in the suburban ring. For example, compared to staying in the city, the odds of moving to urban destinations are 1.13 (1/0.888) times lower for Russians than for Estonians, but the odds of moving to rural destinations are 6.41 times (1/0.156) lower for Russians than for Estonians.

These results suggest that the concentration of ethnic minorities in the core cities and urban municipalities in the suburban rings increases due to selective ethnic migration. We controlled for socio-economic status/economic resources by including the level of education and occupation in the model. Since ethnic differences still remained highly significant, we can argue that economic resources do not explain the ethnic selectivity of moves to suburban areas. Instead, differences in destination choices are assumed to be caused by differences in preference with regard to residential environments, i.e. urban destinations provide better ethnic infrastructure and community support for minorities than rural destinations, and the living environment there is more familiar for them compared to Estonian-dominated rural areas.

\section{[TABLE 2 ABOUT HERE]}

The parameter estimates of the control variables are largely as expected. Women are slightly less likely to move to rural municipalities in the suburban ring than men (compared to staying in the city and moving to urban municipalities in the suburbs). The probability of suburbanisation is highest for the younger birth cohorts, and this decreases with age. Occupation was found to be a good predictor of suburbanisation as well. Those in managerial positions are the most likely to suburbanise, especially to rural destinations in the suburban ring. Managers are likely to enjoy good incomes and they are found to move to the most attractive suburban housing (cf. Kährik and Tammaru 2008). Finally, the model shows that those living in the largest cities are the most likely to suburbanise to urban areas in the suburban ring and those living in county-seat cities are the most likely to move to rural areas in the suburban ring. By including this variable we controlled for some of the structural housing-market differences between urban regions.

The model with a minority population only, in Table 2, allows us to examine more closely the role of ethnic-minority-specific characteristics in suburbanisation. The results show that other (non-Russian speaking) ethnic groups have the highest probability of moving from cities to suburban (both urban and rural) areas. They are probably the least sensitive of all ethnic groups to the existence of a Russian-language-based ethnic-specific infrastructure such as schools.

There is some evidence that minority suburbanisation differs by immigrant generation. The foreign-born are more likely to move to urban municipalities and less likely to move to rural municipalities compared to other minorities. Although the differences are not statistically significant, we think they are still meaningful as we are working with data which include the whole minority population of Estonia, not a sample. So we could carefully argue that the longer ethnic minorities live in Estonia, the more likely they are to move away from traditional ethnic concentration areas. The results for other variables which measure ties with the majority population and host country are more straightforward. Those with Estonian- 
language proficiency and Estonian citizenship are the most likely to move to rural municipalities within the suburban ring. Minorities who do not speak Estonian, or who have Russian citizenship, are the most likely to stay in core cities. Furthermore, ethnic minorities with an Estonian partner have 3.3 times higher odds of moving to rural municipalities in the suburban ring than singles and those with a minority partner.

The effects of age, level of education and labour-market characteristics for minorities are similar to those for the whole population, reflecting similar underlying causes of suburbanisation among members of the minority and majority populations. The probability of suburbanising decreases with age, but the age effect on the probability of moving to rural areas is less pronounced than for the entire population. Those with a university education are the least likely to suburbanise. Ethnic minorities in managerial occupations are the most likely to suburbanise, especially to rural destinations. As found for the whole population, those living in the capital-city urban region are the most likely to move to urban areas in the suburban ring. These satellite towns around the capital city have a well-established ethnic infrastructure and this seems to be an important trigger of minority moves to suburban destinations.

\section{Discussion and Conclusions}

The results of the study confirm our first hypothesis: ethnic minorities were less likely to move from core cities to the suburban ring than members of the majority population during the 1989 and 2000 inter-census period. Such elevated out-migration of the majority population from core cities implies that these cities become more ethnically concentrated (Figure 1, Model 1). Based on the literature, the three important explanations for ethnic differences in mobility relate to discriminatory practices on the housing market, the availability of economic resources for different ethnic groups, and differences in the preferences for residential environment between ethnic groups (Bolt and van Kempen 2010; Krysan and Farley 2002; Simon 2011). There is no direct evidence that ethnic minorities have faced discrimination in Estonia on the housing market (they actually gained from the housing reform that transformed tenants living in the post-World War II houses into home-owners), and we controlled for socio-economic characteristics in our analysis. This implies that the differences in mobility rates found in this study could be due to differences in preference, related to the availability of an ethnic infrastructure such as Russian-language kindergartens and schools. A higher presence of co-ethnics and a higher density of ethnic infrastructure in cities relative to the suburban ring are factors that are the most likely to reduce minority suburbanisation in Estonia.

Two other findings support the preference argument. First, Russian-speakers (Russians, Ukrainians and Byelorussians) are more likely to stay in cities than other minority groups who do not benefit from Russian-language ethnic facilities. Second, minorities are less likely to settle in rural municipalities compared to Estonians. In other words, the presence of co-ethnics and the availability of an ethnic infrastructure seem to increase the immobility of (Russianspeaking) ethnic minorities on the one hand and to shape destination choice on the other, making them more likely to move into urban municipalities (secondary ethnic clusters) in the suburbs (Figure 1, Model 3). It follows that, as the dispersion process starts to operate, it is gradual by nature, i.e. many minorities do not move to a completely different residential context compared to where they used to live before (cf. Li 2009; Lichter et al. 2010).

The results also confirm our second hypothesis: ethnic minorities who show strong ties with the majority population and the host country (e.g. by speaking Estonian, having Estonian citizenship, living with an Estonian partner), are the most likely to settle in rural municipalities in the suburban ring (Figure 1, Model 2). In other words, ties with the majority 
population and the host country increase co-residence (spatial assimilation) with the majority population in the suburban ring (cf. Clark 2006; Kraus and Koresh 1992). Living with an Estonian partner has an especially strong effect on moves to rural municipalities in the suburban ring.

This study has provided new insights into the ethnic dimensions of suburbanisation patterns in a country that was once part of the Soviet Union. Our findings show that suburbanisation has an effect on ethnic concentration in cities and suburban locations. Cities and urban areas in the suburban ring are becoming more ethnically concentrated. Rural municipalities in the suburban ring have remained residential locations for ethnic Estonians and for those minorities who have established close ties with the majority population in their host society. It remains to be seen whether the dispersion process from primary ethnic clusters in cities to secondary ethnic clusters in suburbs will be filtering down to non-ethnic areas as well in the course of time.

\section{Acknowledgments}

We are grateful for the valuable comments of two anonymous JEMS referees, and for the financial support provided by the Estonian Ministry of Education and Science (Target Financed Research Project No. SF0180052s07), the Estonian Science Foundation (Grant Nos 7588 and 8774) and the NORFACE research programme Migration in Europe-Social, Economic, Cultural and Policy Dynamics.

\section{References}

Alba, R., Logan, J., Stults, B., Marzan, G. and Zhang, W. (1999) 'Immigrant groups in the suburbs: a re-examination of suburbanisation and spatial assimilation', American Sociological Review, 64(3): 446-60.

Barrett, G. and McEvoy, D. (2006) 'The evolution of Manchester's Curry Mile: from suburban shopping street to ethnic destination', in Kapland, D. and Li, W. (eds) Landscapes of the Ethnic Economy. Lanham, Md: Rowman and Littlefield, 183-204.

Bobo, L. and Zubrinsky, C. (1996) 'Attitudes on residential integration: perceived status differences, mere in-group preference, or racial prejudice?', Social Forces, 74(3): 883909.

Bolt, G. and van Kempen, R. (2010) 'Ethnic segregation and residential mobility: relocations of minority ethnic groups in the Netherlands', Journal of Ethnic and Migration Studies, 36(2): 333-54.

Bolt, G., van Kempen, R. and van Ham, M. (2008) 'Minority ethnic groups in the Dutch housing market: spatial segregation, relocation dynamics and housing policy', Urban Studies, 45(7): 1359-84.

Bonvalet, C., Carpenter, J. and White, P. (1995) 'The residential mobility of ethnic minorities: a longitudinal analysis', Urban Studies, 32(1): 87-103.

Borén, T. and Gentile, M. (2007) 'Metropolitan processes in post-communist states: an introduction', Geografiska Annaler, 89B(2): 95-110.

Brubaker, R. (2001) 'The return of assimilation? Changing perspectives on immigration and its sequels in France, Germany, and the United States', Ethnic and Racial Studies, 24(4): 531-48.

Clark, W.A.V. (1991) 'Residential preferences and neighbourhood racial segregation: a test of the Shelling segregation model', Demography, 28(1): 1-19.

Clark, W.A.V. (2006) 'Race, class, and space: outcomes of suburban access for Asians and Hispanics', Urban Geography, 27(6): 489-506. 
Crowder, K., Hall, M. and Tolnay, S. (2011) 'Neighborhood immigration and native outmigration', American Sociological Review, 76(1): 25-47.

Finney, N. and Simpson, L. (2008) 'Internal migration and ethnic groups: evidence for Britain from the 2001 census', Population, Space and Place, 14(2): 63-83.

Finney, N. and Simpson, L. (2009) 'Spatial patterns of internal migration: Evidence for ethnic groups in Britain', Population, Space and Place, 15(1): 37-56.

Frey, W. and Liaw, K.-L. (1998) 'Immigrant concentration and domestic migrant dispersal: is movement to non-metropolitan areas "White Flight"?', Professional Geographer, 50(2): 215-32.

Gentile, M. and Sjöberg, Ö. (2010) 'Spaces of priority: the geography of Soviet housing construction in Daugavpils, Latvia', Annals of the Association of American Geographers, 100(1): 112-36.

Gentile, M. and Tammaru, T. (2006) 'Ethnicity and housing in Ust'-Kamenogorsk, Kazakhstan', Urban Studies, 43(10): 1757-78.

Golubchikov, O. and Phelps, N. (2011) 'The political economy of place at the post-socialist urban periphery: governing growth on the edge of Moscow', Transactions of the Institute of British Geographers, 36(3): 425-40.

Goodwin-White, J. (2007) 'Dispersion or concentration for the 1.5 generation?', Population, Space and Place, 13(5): 313-31.

Hirt, S. (2006) 'Suburbaninizing Sofia: characteristics of peri-urban change', Urban Geography, 28(8): 755-80.

Hou, F. (2006) 'Spatial assimilation of racial minorities in Canada's immigrant gateway cities', Urban Studies, 43(7): 1191-213.

Kährik, A. and Tammaru, T. (2008) 'Population composition in new suburban settlements of the Tallinn metropolitan area', Urban Studies, 45(5): 1055-78.

Kährik, A, and Tammaru, T. (2010) 'Soviet prefabricated panel housing estates: areas of continued social mix or decline? The case of Tallinn', Housing Studies, 25(2): 201-19.

Kaiser, R. (1995) 'Nationalizing the work force: ethnic restratification in the newly independent states', Post-Soviet Geography and Economics, 36(2): 87-111.

Konrád, G. and Szelényi, I. (1974) 'Social conflicts and urbanisation', in Brown, A., Licari, J. and Neuberger, E. (eds) Urban and Social Economics in Market and Planned Economies: Policy, Planning, and Development. New York: Praeger, 206-26.

Kraus, V. and Koresh, Y. (1992) 'The course of residential segregation: ethnicity, socioeconomic status, and suburbanization in Israel', Sociological Quarterly, 33(2): 30319.

Krišjāne, Z. and Bērziņš, M. (2011) 'Post-socialist urban trends: new patterns and motivations for migration in the suburban areas of Riga, Latvia', Urban Studies.

Krysan, M. and Farley, R. (2002) 'The residential preferences of blacks: do they explain persistent segregation?', Social Forces, 80(3): 937-80.

Kulu, H. (2003) 'Housing differences in the late Soviet city: the case of Tartu, Estonia', International Journal of Urban and Regional Research, 27(4): 897-911.

Laitin, D. (1998) Identity in Formation. The Russian Speaking Population in the Near Abroad. New York: Cornell University Press.

Lappo, G. (1992) 'Urban policy in Russia: a geographic perspective', Post-Soviet Geography, 33(8): 516-32.

Leetmaa, K., Tammaru, T. and Anniste, K. (2009) 'From priorities- to market-led suburbanisation in a post-communist metropolis', Tijdschrift voor Economische en Sociale Geografie, 100(4): 436-53.

Li, W. (2009) Ethnoburb. The New Ethnic Community in Urban America. Hawaii: University of Hawaii Press. 
Lichter, D., Parisi, D., Taquino, M. and Grice, S. (2010) 'Residential segregation in new Hispanic destinations: cities, suburbs, and rural communities compared', Social Science Research, 39(2): 215-30.

Lindemann, K. and Saar, S. (2008) 'Non-Estonians in the labour market', in Estonian Human Development Report. Tallinn: Eesti Ekspressi Kirjastuse AS, 95-9.

Logan, J., Alba, R. and Leung S.-Y. (1996) 'Minority access to white suburbs: a multiregional comparison', Social Forces, 74(3): 851-81.

Marcińczak, S. and Sagan, I. (2011) 'The socio-spatial restructuring of Łódź, Poland', Urban Studies, 48(9): 1789-809.

Massey, D. and Denton, N. (1988) 'Suburbanization and segregation in U.S. metropolitan areas', American Journal of Sociology, 94(3): 592-626.

Muñoz, S.-A. (2011) 'Ethno-faith-burbs: religious affiliation and residential patterns of the Indian ethnic populations of Dundee and Glasgow', Journal of Intercultural Studies, 32(2): $115-31$.

Newbold, K.B. (1996) 'Internal migration of the foreign-born in Canada', International Migration Review, 30(3): 728-47.

Ouředníček, M. (2007) 'New suburban development in the post-socialist city: the case of Prague', Geografiska Annaler, 89B(2): 111-26.

Painter, G. and Zhou, Y. (2008) 'Leaving gateway metropolitan areas in the United States: immigrants and the housing market', Urban Studies, 45(5): 1163-92.

Pamuk, A. (2004) Immigrant Clusters and Homeownership in Global Metropolises: Suburbanization Trends in San Francisco, Los Angeles, and New York. Institute of Urban and Regional Development, Working Paper No. 2004-02.

Peach, C. (2010) 'Slippery segregation: discovering or manufacturing ghettos?', Journal of Ethnic and Migration Studies, 35(9): 1381-95.

Randolph, B. and Holloway, D. (2005) 'The suburbanization of disadvantage in Sydney: new problems, new policies', Opolis, 1(1): 49-65.

Rannut, M. (2008) 'Estonianization efforts post-independence', International Journal of Bilingual Education and Bilingualism, 11(5): 423-39.

Simon, A. (2011) 'White mobility and minority ethnic concentrations: exploring internal migration patterns for electoral wards in England and Wales using the 2001 Census', Journal of Intercultural Studies, 32(2): 173-88.

Smith, D.M. (1996) 'The socialist city', in Andrusz, G., Harloe, M. and Szelényi, I. (eds) Cities After Socialism: Urban and Regional Change and Conflict in Post-Socialist Cities. Oxford: Blackwell, 70-99.

Stillwell, J. (2010) 'Ethnic population concentration and net migration in London', Environment and Planning A, 42(6): 1439-56.

Stillwell, J. and Hussain, S. (2010) 'Exploring the ethnic dimension of internal migration in Great Britain using migration effectiveness and spatial connectivity', Journal of Ethnic and Migration Studies, 36(9): 1381-403.

Sýkora, L. (2009) 'Post-socialist cities', in Kitchin, R. and Thrift, N. (eds) International Encyclopedia of Human Geography. Volume 8. Oxford: Elsevier, 387-95.

Tammaru, T. (2001) 'Suburban growth and suburbanization under central planning: the case of Soviet Estonia', Urban Studies, 38(8): 1314-57. 
Tammaru, T. and Kontuly, T. (2011) 'Selectivity and destinations of ethnic minorities leaving the main gateway cities of Estonia', Population, Space and Place, 17(5): 674-88.

Tammaru, T. and Kulu, H. (2003) 'Ethnic minorities in Estonia: changes in the size, composition and location', Eurasian Geography and Economics, 44(2): 105-20.

Tammaru, T. and Leetmaa, K. (2007) 'Suburbanisation in relation to education in the Tallinn metropolitan area', Population, Space and Place, 13(4): 279-92.

Teixeira, C. (2007) 'Residential experiences and the culture of suburbanization: a case study of Portuguese homebuyers in Mississauga', Housing Studies, 22(4): 495-521.

Temelová, J., Novák, J., Ouředníček, M. and Puldová, P. (2011) 'Housing estates in the Czech Republic after socialism: various trajectories and inner differentiation', Urban Studies, 48(9): 1811-34.

Timár, J. and Váradi, D. (2001) 'The uneven development of suburbanisation during transition in Hungary', European Urban and Regional Studies, 8(4): 349-60.

Toomet, O.-S. (2011) 'Learn English, not the local language! Ethnic Russians in the Baltic States', American Economic Review, 101(3): 526-31.

van Ham, M. and Clark, W.A.V. (2009) 'Neighbourhood mobility in context: household moves and changing neighbourhoods in the Netherlands', Environment and Planning A, 41(6): 1442-59.

van Ham, M. and Feijten, P.M. (2008) 'Who wants to leave the neighbourhood? The effect of being different from the neighbourhood population on wishes to move', Environment and Planning A, 40(5): 1151-70.

van Ham, M. and Tammaru, T. (2011) 'Ethnic minority-majority unions in Estonia', European Journal of Population, 27(3): 313-35.

Vihalemm, T. (1999) 'Group identity formation processes among Russian-speaking settlers of Estonia: a linguistic perspective', Journal of Baltic Studies, 30(1): 18-39.

Wen, M., Lauderdale, D.S. and Kandula, N.R. (2009) 'Ethnic neighborhoods in multi-ethnic America, 1990-2000: resurgent ethnicity in the ethnoburbs', Social Forces, 88(1): 425-60. 
Figure 1. Three models showing how minority and majority suburbanisation could change the ethnic landscape in metropolitan areas
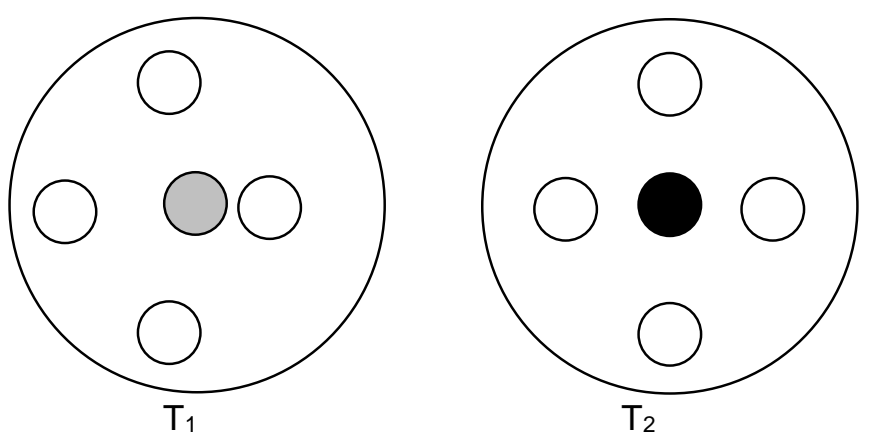

Model 1. Low suburbanisation rate of ethnic minorities and high suburbanisation rate of the majority population lead to increased segregation.
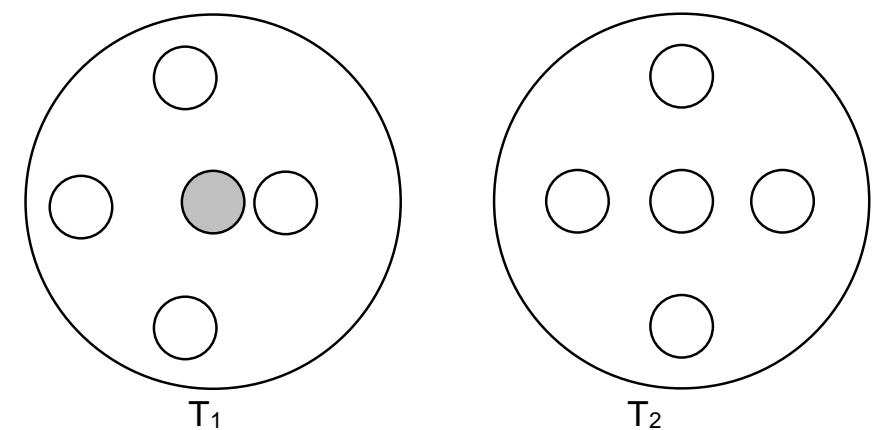

Model 2. Similar destinations of all suburbanising groups lead to increased minority-majority coresidence.
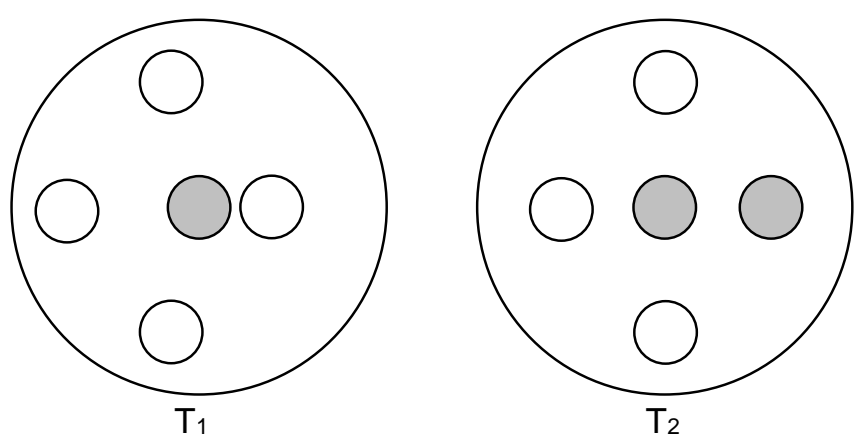

Model 3. Different destinations of suburbanisers lead to the formation of suburban ethnic clusters.

Notes: Outer circle denotes the boundary of the suburban ring; small circle in the centre denotes core cities; other small circles represent residential locations in the suburban ring; white, grey and black shading indicates an increasing share of the minority population; $T_{1}$ refers to time $1 ; T_{2}$ refers to time 2. 
Figure 2. Urban regions of Estonia

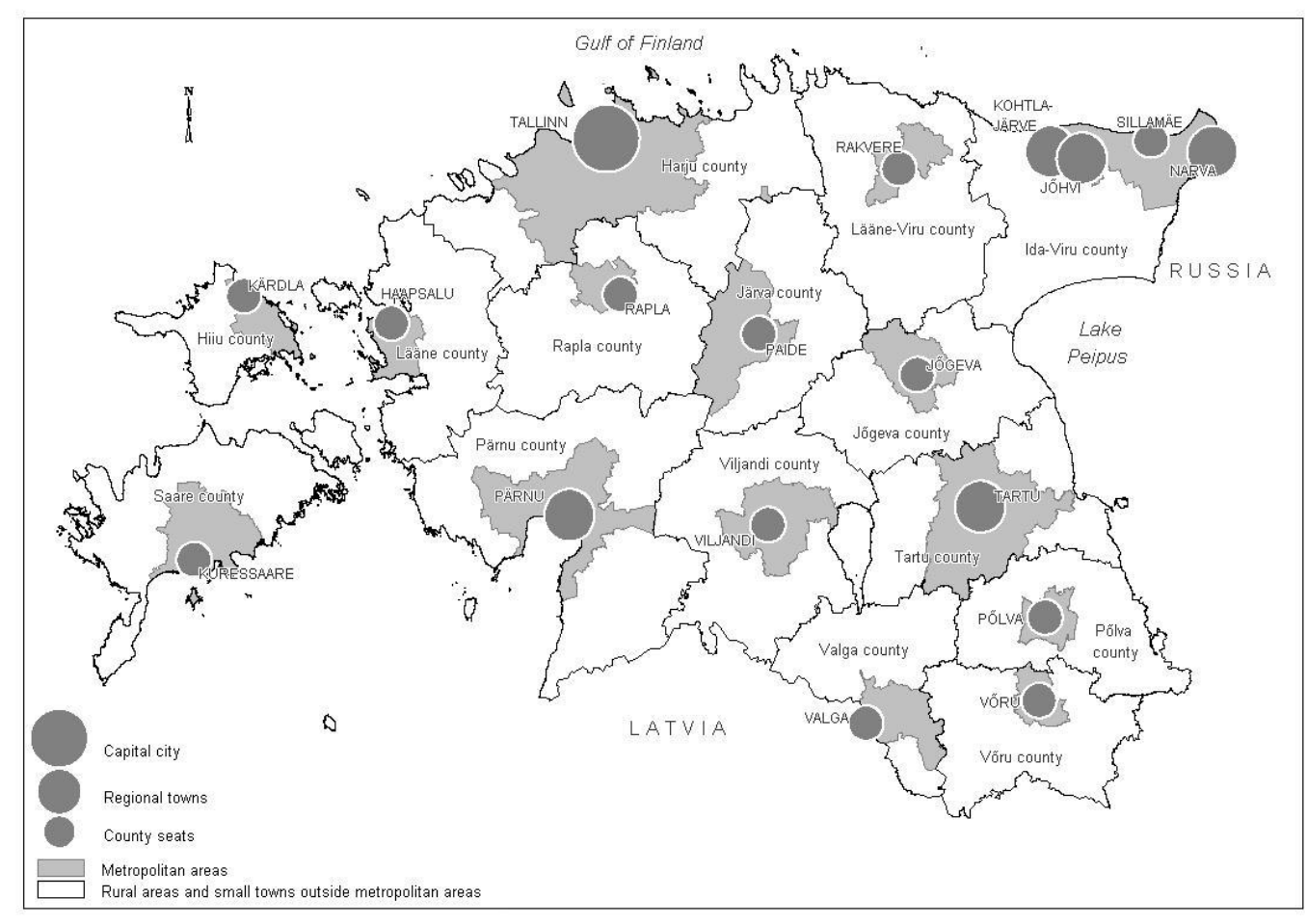


Table 1. Compositional differences between Estonians and ethnic minorities in the research population (\%)

\begin{tabular}{|c|c|c|c|c|}
\hline & & Estonians & Minorities & Total \\
\hline \multirow{4}{*}{$\begin{array}{l}\text { Immigrant } \\
\text { generation }\end{array}$} & Born Estonia, parents Estonia-born & 84 & 8 & 53 \\
\hline & Born Estonia, one parent foreign-born & 11 & 13 & 12 \\
\hline & Born Estonia, parents foreign-born & 3 & 27 & 13 \\
\hline & Foreign born & 2 & 52 & 22 \\
\hline \multirow[t]{2}{*}{ Gender } & Female & 55 & 56 & 55 \\
\hline & Male & 45 & 44 & 45 \\
\hline \multirow[t]{7}{*}{ Age } & $20-29$ & 15 & 15 & 15 \\
\hline & 30-39 & 16 & 14 & 15 \\
\hline & $40-49$ & 15 & 15 & 15 \\
\hline & $50-59$ & 15 & 20 & 17 \\
\hline & $60-69$ & 14 & 13 & 14 \\
\hline & $70-79$ & 13 & 13 & 13 \\
\hline & $80+$ & 11 & 10 & 11 \\
\hline \multirow[t]{2}{*}{ Family status } & In union & 42 & 48 & 44 \\
\hline & Not in union & 58 & 52 & 56 \\
\hline \multirow[t]{3}{*}{ Education } & Primary & 43 & 40 & 42 \\
\hline & Secondary & 40 & 46 & 42 \\
\hline & Tertiary & 17 & 14 & 16 \\
\hline \multirow[t]{2}{*}{ Dwelling } & Multi-family & 72 & 96 & 82 \\
\hline & Single-family & 28 & 4 & 18 \\
\hline \multirow{2}{*}{$\begin{array}{l}\text { Place of } \\
\text { residence }\end{array}$} & Urban & 77 & 96 & 85 \\
\hline & Rural & 23 & 4 & 15 \\
\hline \multirow{7}{*}{$\begin{array}{l}\text { Location in } \\
\text { metropolitan } \\
\text { space }\end{array}$} & Tallinn & 24 & 44 & 30 \\
\hline & Suburban ring around Tallinn & 6 & 4 & 5 \\
\hline & Regional towns & 14 & 36 & 22 \\
\hline & Suburban rings around regional towns & 4 & 2 & 4 \\
\hline & County seats & 12 & 4 & 9 \\
\hline & Suburban rings around county seats & 5 & 1 & 4 \\
\hline & Outside urban regions & 35 & 9 & 26 \\
\hline \multicolumn{2}{|l|}{$\mathrm{N}$} & 489,252 & 334,406 & 823,658 \\
\hline
\end{tabular}


Table 2. Multinomial logistic regression model of residential mobility destinations (odds ratios)

\begin{tabular}{|c|c|c|c|c|c|c|c|c|}
\hline & \multicolumn{4}{|c|}{$\begin{array}{l}\text { Model with entire population } \\
\text { Suburbanisers to: }\end{array}$} & \multicolumn{4}{|c|}{$\begin{array}{c}\text { Model with minority population only } \\
\text { Suburbanisers to: }\end{array}$} \\
\hline & \multicolumn{2}{|c|}{ Urban areas } & \multicolumn{2}{|c|}{ Rural areas } & \multicolumn{2}{|c|}{ Urban areas } & \multicolumn{2}{|c|}{ Rural areas } \\
\hline & $\operatorname{Exp}(B)$ & Sig. & $\operatorname{Exp}(B)$ & Sig. & $\operatorname{Exp}(B)$ & Sig. & $\operatorname{Exp}(B)$ & Sig. \\
\hline \multicolumn{9}{|l|}{ Ethnicity } \\
\hline Estonian & 1.000 & & 1.000 & & & & & \\
\hline Russian & 0.888 & $* \star *$ & 0.156 & 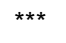 & 1.000 & & 1.000 & \\
\hline Ukrainian & 0.879 & * & 0.228 & $* * *$ & 0.952 & & 1.297 & $* * *$ \\
\hline Byelorussian & 0.993 & & 0.159 & $* * \star$ & 1.064 & & 0.975 & \\
\hline Other & 1.124 & & 0.265 & $\star * \star$ & 1.252 & $* * *$ & 1.247 & $* * *$ \\
\hline \multicolumn{9}{|l|}{ Immigrant generation } \\
\hline First/foreign-born & & & & & 1.000 & & 1.000 & \\
\hline Second & & & & & 0.897 & & 1.075 & \\
\hline Third & & & & & 0.850 & ** & 1.066 & \\
\hline \multicolumn{9}{|l|}{ Speaks Estonian } \\
\hline No & & & & & 1.000 & & 1.000 & \\
\hline Yes & & & & & 0.852 & $* * *$ & 1.288 & $* * *$ \\
\hline \multicolumn{9}{|l|}{ Partner ethnicity } \\
\hline Single & & & & & 1.000 & & 1.000 & \\
\hline Estonian & & & & & 1.182 & * & 3.255 & $* * *$ \\
\hline Minority & & & & & 1.051 & & 0.999 & \\
\hline \multicolumn{9}{|l|}{ Citizenship } \\
\hline Estonian & & & & & 1.000 & & 1.000 & \\
\hline Russian & & & & & 0.892 & * & 0.537 & $* * *$ \\
\hline Other country & & & & & 1.006 & & 0.859 & \\
\hline Not chosen & & & & & 1.076 & & 0.833 & $* * *$ \\
\hline \multicolumn{9}{|l|}{ Gender } \\
\hline Male & 1.000 & & 1.000 & & 1.000 & & 1.000 & \\
\hline Female & 1.025 & & 0.926 & $* * *$ & 1.115 & $* * *$ & 0.858 & $* * *$ \\
\hline \multicolumn{9}{|l|}{ Birth cohort } \\
\hline After 1970 & 1.000 & & 1.000 & & 1.000 & & 1.000 & \\
\hline 1960-69 & 1.133 & $* * *$ & 1.094 & 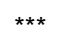 & 1.113 & * & 1.231 & $* * *$ \\
\hline $1950-59$ & 0.676 & $* * *$ & 0.697 & $* * \star$ & 0.658 & $* * \star$ & 1.014 & \\
\hline $1940-49$ & 0.499 & $* * *$ & 0.636 & $* * *$ & 0.455 & $* * \star$ & 1.059 & \\
\hline $1930-39$ & 0.388 & $* * *$ & 0.465 & $* * *$ & 0.364 & $* \star *$ & 0.904 & \\
\hline Before 1930 & 0.319 & $* * *$ & 0.264 & $* * *$ & 0.285 & $* * *$ & 0.579 & $* * *$ \\
\hline \multicolumn{9}{|l|}{ Level of education } \\
\hline Primary & 1.000 & & 1.000 & & 1.000 & & 1.000 & \\
\hline Secondary & 0.842 & $* * *$ & 0.954 & & 1.123 & & 0.935 & \\
\hline University & 0.870 & $* * *$ & 0.885 & $* * *$ & 0.877 & $* * *$ & 0.901 & ** \\
\hline In education & 0.703 & $* * *$ & 0.965 & * & 0.664 & $* * *$ & 0.799 & $* * *$ \\
\hline \multicolumn{9}{|l|}{ Occupation } \\
\hline Inactive & 1.000 & & 1.000 & & 1.000 & & 1.000 & \\
\hline Manager & 1.185 & $* * *$ & 1.473 & $* * *$ & 1.213 & ** & 2.393 & $* * *$ \\
\hline Other white collar & 0.667 & & 0.321 & $* * \star$ & 0.510 & & 0.239 & ** \\
\hline Blue collar & 0.801 & & 0.347 & $* * \star$ & 0.595 & & 0.260 & * \\
\hline Unemployed & 0.491 & $* * *$ & 0.459 & $* * \star$ & 0.387 & $* * *$ & 0.521 & $* * *$ \\
\hline \multicolumn{9}{|l|}{ Region of residence } \\
\hline Capital city UR & 1.000 & & 1.000 & & 1.000 & & 1.000 & \\
\hline Regional town UR & 0.212 & $* * *$ & 0.922 & $* * *$ & 0.149 & $* * *$ & 0.780 & $* * *$ \\
\hline County seat UR & 0.259 & $* * *$ & 1.251 & $* * \star$ & 0.111 & *** & 2.348 & $* * *$ \\
\hline
\end{tabular}

Notes: Reference category is stayers in core cities; significance: ${ }^{*} p<0.10^{* \star} p<0.05{ }^{* \star *} p<0.01$ 